https://doi.org/10.35339/ekm.2019.83.02.04

УДК 61.89:615.851:616-07

\author{
А.О. Камінська ${ }^{1}$, Н.К. Агішева
}

${ }^{1}$ Вінницький національний медичний університет ім. М.І. Пирогова ${ }^{2}$ Харківська медична академія післядипломної освіти

\title{
ПСИХОСОЦІАЛЬНИЙ КОНТЕКСТ ФУНКЦІОНУВАННЯ СІМ'Ї, ДЕ ПРОЖИВАЄ ХВОРИЙ З ЕНДОГЕННИМ ПСИХІЧНИМ РОЗЛАДОМ
}

\begin{abstract}
Досліджували психосоціальні особливості референтних родичів пацієнтів з ендогенними психічними розладами. Було обстежено 243 референтні родичі хворих на параноїдну шизофренію (168 осіб) та хворих на афективні розлади - біполярний афективний розлад, рекурентний депресивний розлад (75 осіб). Групу контролю склали 55 психічно здорових осіб. У дослідженні використовували шкалу оцінки навантаження на сім'ю (ECI, Experience of Caregiving Inventory) за G. Szmukler et al. (1994) та шкалу структурованого інтерв'ю для визначення ставлення членів сім'ї до хвороби (психіатричного діагнозу) у родича за В.А. Абрамовим, І.В. Жигуліною, Т.Л. Ряполовою. Встановлені особливості свідчать про те, що в процесі розвитку ендогенного психічного розладу у члена сім'ї у референтних родичів поступово зростає рівень сімейного навантаження за всіма конструктами із одночасним виснаженням емоційних, індивідуально-психологічних та комунікативних ресурсів. Дослідження типології ставлення референтних родичів до наявності психічного захворювання у члена сім'ї дозволило виділити певні особливості, які визначались загальною тривалістю патологічного процесу у пацієнтів. Так, на початкових етапах розвитку хвороби (до 4-х років) переважав адекватний тип ставлення, що створює сприятливе підгрунтя для медико-психологічних втручань. Натомість, в процесі розвитку патологічного процесу, з боку референтних родичів починають переважати драматизуючий та негативний типи ставлення $(\mathrm{P}<0,001)$. Прийняття хвороби сім'єю та усвідомлене ставлення до їі проявів у поєднанні з психологічною готовністю брати участь у забезпеченні психосоціальної реабілітації та реадаптації психічно хворого члена сім'ї - важливий фактор у лікуванні ендогенних психічних розладів.
\end{abstract}

Ключові слова: ресоціалізачія, родина, дистрес, психічно хворі, внутрішньосімейні чинники.

\section{Вступ}

Факторами, що позитивно впливають на успішність терапевтичних та реабілітаційних заходів для хворих на шизофренію та афективні розлади у позалікарняних умовах, $є$ наявність зацікавленості найближчого оточення в реабілітації пацієнтів, вихідне збереження соціального функціонування у сферах соціально-корисної діяльності й взаємин з людьми $[1,2]$. Відомо, що до 60 \% усіх пацієнтів, які виписуються із психіатричних стаціонарів, повертаються у сім'ї, при цьому переважна більшість із них зберігають контакти зі своїми рідними [3-5]. Тисячі сімей щорічно стикаються 3 психічними розладами і змушені вирішувати пов'язані з цим проблеми $[6,7]$.

Внутрішньосімейні фактори можуть чинити як негативний вплив на перебіг ендогенних психічних розладів (ЕПР) і соціальну адаптацію хворих, коли неправильне сприймання хвороби і хворого референтними родичами (РР) призводить до реалізації неадаптивних поведінкових паттернів, а нерозуміння членами сім'ї того, що зміни у поведінці хворого пов'язані із

(C) А.О. Камінська, Н.К. Агішева, 2019 
психічним розладом, призводить до відтягування моменту звернення до психіатра, нехтування медикаментозною терапією, а іноді до упередженого та негативного ставлення до хворого, що сприяє рецидивам та екзацербації захворювання; так і впливати позитивно - шляхом формування системи соціальної підтримки, тобто форми допомоги у копінгу відповідно до вимог навколишнього середовища, що позитивно позначається на адаптації та соціальному функціонуванні пацієнта [8-10].

Через відсутність належної психоосвітньої підготовки, недостатні знання про хворобу та психологічний дистрес, обумовлений різкими та непередбачуваними змінами у психічному стані члена сім'ї, референтні родичі зазнають значного навантаження у багатьох сферах життя, яке відоме під назвою «сімейне навантаження» [11-13]. Об'єктивні негативні наслідки проживання та взаємодії із психічно хворим членом сім'ї включають погіршення фізичного здоров'я та якості життя РР, порушення сімейної взаємодії, збільшення витрат у зв'язку з необхідністю госпіталізацій та лікування, тоді як суб'єктивні ефекти включають психоемоційні наслідки: почуття ізоляції, втрати, тривогу, гнів та фрустрацію $[14,15]$.

Специфічною особливістю психосоціальної терапії та психосоціальної реабілітації хворих з ЕПР є особливе значення, яке надається активному залученню РР до лікувально-реабілітаційного процесу з метою досягнення та утримання максимально високого рівня соціального функціонування пацієнта. Особливого значення набуває дослідження індивідуальнопсихологічних, поведінкових, психосоціальних та інтерперсонально-комунікативних особливостей РР пацієнтів з ЕПР, що пояснюється необхідністю розробки відповідної системи медико-психологічного супроводу безпосередньо для членів сім'ї пацієнтів з ЕПР для забезпечення оптимального розкриття соціально-терапевтичного потенціалу сім'ї.

На сьогодні звертає на себе увагу як невелика кількість наукових досліджень у цьому напрямку, так і відсутність комплексних систем медико-психологічного супроводу для сімей, де проживають пацієнти з ЕПР.

У зв'язку з цим метою нашого дослідження було вивчення психосоціальних особливостей референтних родичів пацієнтів 3 ЕПР для оцінки соціально-терапевтичного потенціалу сім'ї та подальшої розробки відповідної комплексної системи медико-психоло- гічного супроводу сімей, де проживають пацієнти з ЕПР.

\section{Матеріал і методи}

3 дотриманням принципів біоетики та медичної деонтології та за умови інформованої згоди було обстежено 243 референтні родичі хворих на параноїдну шизофренію (168 осіб, РРПШ) та хворих на афективні розлади - біполярний афективний розлад, рекурентний депресивний розлад (75 осіб, РРАФР). Критеріями включення респондентів до участі у дослідженні були: інформована згода на проведення анкетування, клініко-психологічного, психодіагностичного обстеження, відсутність попередніх звернень по допомогу до лікаряпсихіатра чи лікаря-нарколога, відсутність черепно-мозкових травм в анамнезі, 1-2-й ступінь спорідненості з хворим. До РРПШ було включено 49 дружин, 25 чоловіків, 94 - один із батьків пацієнтів з ПШ. До РРАФР було включено 20 дружин, 25 чоловіків, 30 - один із батьків пацієнтів з АФР. Обстежені перебували у віковому діапазоні від 26 до 63 років [середній вік: «дружини» $(37,5 \pm 0,8)$ року, «чоловіка» $(42,3 \pm 0,9)$ та «один з батьків» $(60,3 \pm$ $3,7)$ року]. До контрольної групи (КГ) було включено 55 психічно здорових осіб (35 осіб жіночої та 20 осіб чоловічої статі), в сім'ях яких не проживають психічно хворі пацієнти і які ніколи не звертались по допомогу до лікаря-психіатра.

Ступінь навантаження на сім'ю визначався за допомогою шкали оцінки навантаження на сім'ю (ECI, Experience of Caregiving Inventory) [4], розробленої G. Szmukler et al. (1994), що складається з 66 питань, згрупованих у 10 блоків, у свою чергу розподілених на дві субшкали: субшкалу негативних оцінок $\mathrm{i}$ субшкалу позитивних оцінок. Субшкала негативних оцінок включає 8 основних конструктів: проблеми в поведінці; негативні симптоми; стигма; проблеми з психіатричними закладами; вплив на сім'ю; необхідність підтримки хворого; залежність; збитки. Субшкала позитивних оцінок складається із двох конструктів: позитивний досвід і позитивні аспекти взаємин 3 хворим. При відповіді на те чи інше питання РР пацієнта пропонувався на вибір один iз п'яти варіантів відповіді: ніколи (0 балів), рідко (1 бал), іноді (2 бали), часто (3 бали), майже завжди (4 бали). При обробці отриманих даних підраховувалась сума балів за кожним розділом окремо. Результати оцінювались у динаміці (в групах РР пацієнтів з ЕПР з тривалістю захворювання до 4 років (РРПШ1 та 
РРАФР1), від 5 до 8 років (РРПШ2 та РРАФР2) та від 9 до 12 років (РРПШЗ та РРАФР3).

Дослідження суб'єктивного ставлення РР до пацієнтів з ЕПР проводили за шкалою структурованого інтерв'ю для визначення ставлення членів сім'ї до хвороби (психіатричного діагнозу) у родича за В.А. Абрамовим, І.В. Жигуліною, Т.Л. Ряполовою.

\section{Результати та їх обговорення}

Оцінка показників шкали ЕСI в динаміці дозволила проаналізувати зміни сімейного навантаження, що відбуваються в процесі захворювання (рис. 1-2).

Загалом, динаміка середніх показників навантаження на сім'ю характеризується одночасним зростанням показників за одними параметрами та зниженням за іншими зі збільшенням тривалості захворювання у психічно хворого члена сім'ї. За більшістю конструктів субшкали негативної оцінки сімейного навантаження (перші 8 конструктів) показники мають тенденцію до зростання у респондентів РРПШ, тоді як у респондентів РРАФР спостерігається поступова стабілізація та зниження показників сімейного навантаження. Виключенням $є$ показники за конструктом «проблеми із психіатричними закладами», де спостерігалось загальне зниження показників як в РРПШ, так і в РРАФР, що можна пов'язати із набуттям референтними родичами досвіду звернення за спеціалізованою допомогою до відповідних лікувальних закладів.

Помітне зростання рівня навантаження на сім'ю зі збільшенням тривалості захворювання відзначається за конструктами: «проблеми у поведінці», «стигма», «вплив на сім'ю», «збитки» (puc. 1-2). При цьому, загалом у респондентів РРАФР відзначаються нижчі показники у порівнянні з респондентами РРПШ, що імовірно пов'язано із відмінностями у динаміці захворювань та симптоматики. У респондентів РРПШ додатково спостерігається підвищення показників за розділами «негативні симптоми» та «підтримка хворого».

Привертає увагу те, що за субшкалою позитивних оцінок навантаження на сім'ю не виявлено суттєвих відмінностей залежно від тривалості захворювання між респондентами РРПШ та РРАФР.

Якісний аналіз отриманих даних вказує на суб'єктивне сприймання РР психічно хворого члена сім'ї як непередбачуваного, нерозваж-

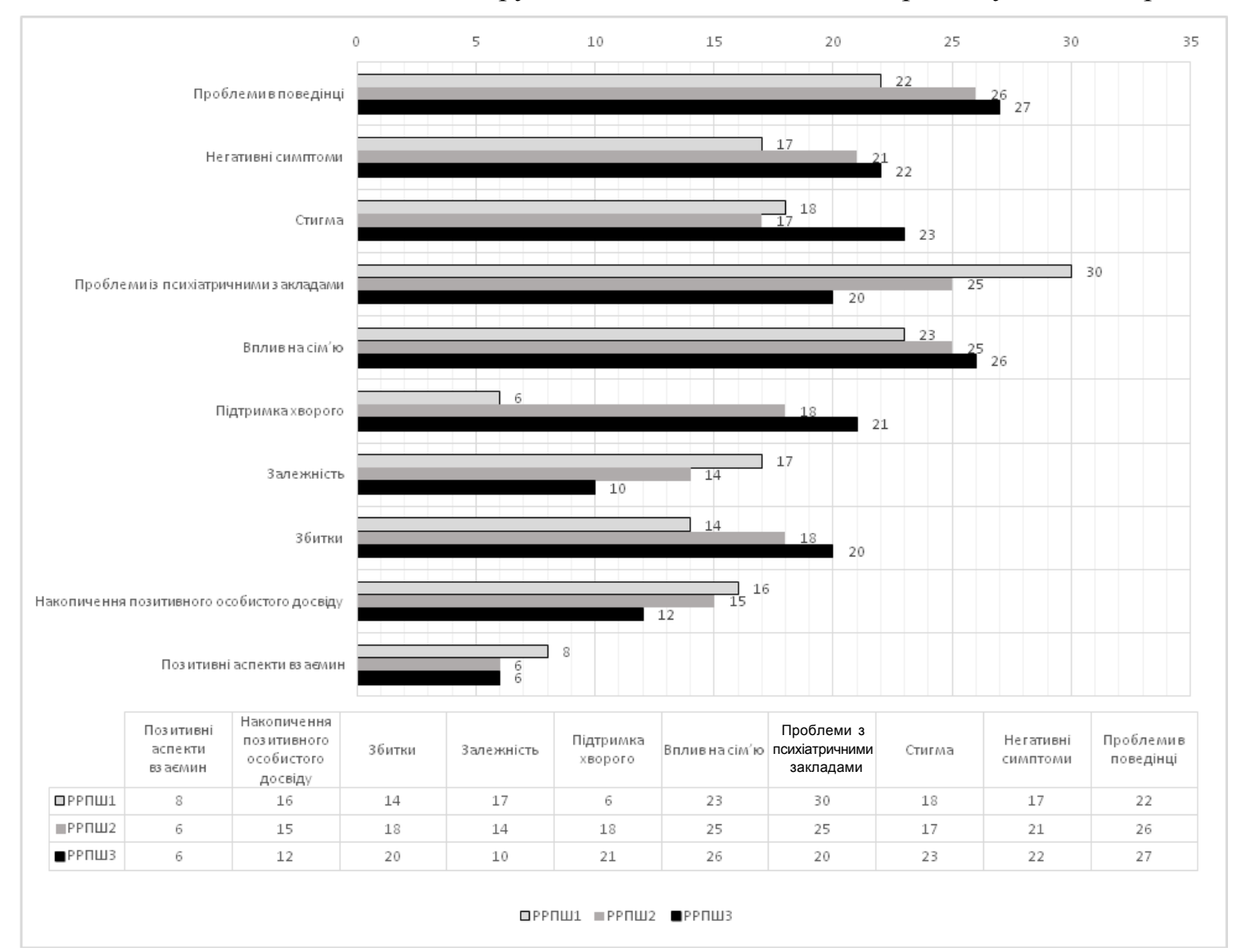

Рис. 1. Рівень сімейного навантаження на референтних родичів пацієнтів з параноїдною шизофренією залежно від тривалості захворювання 


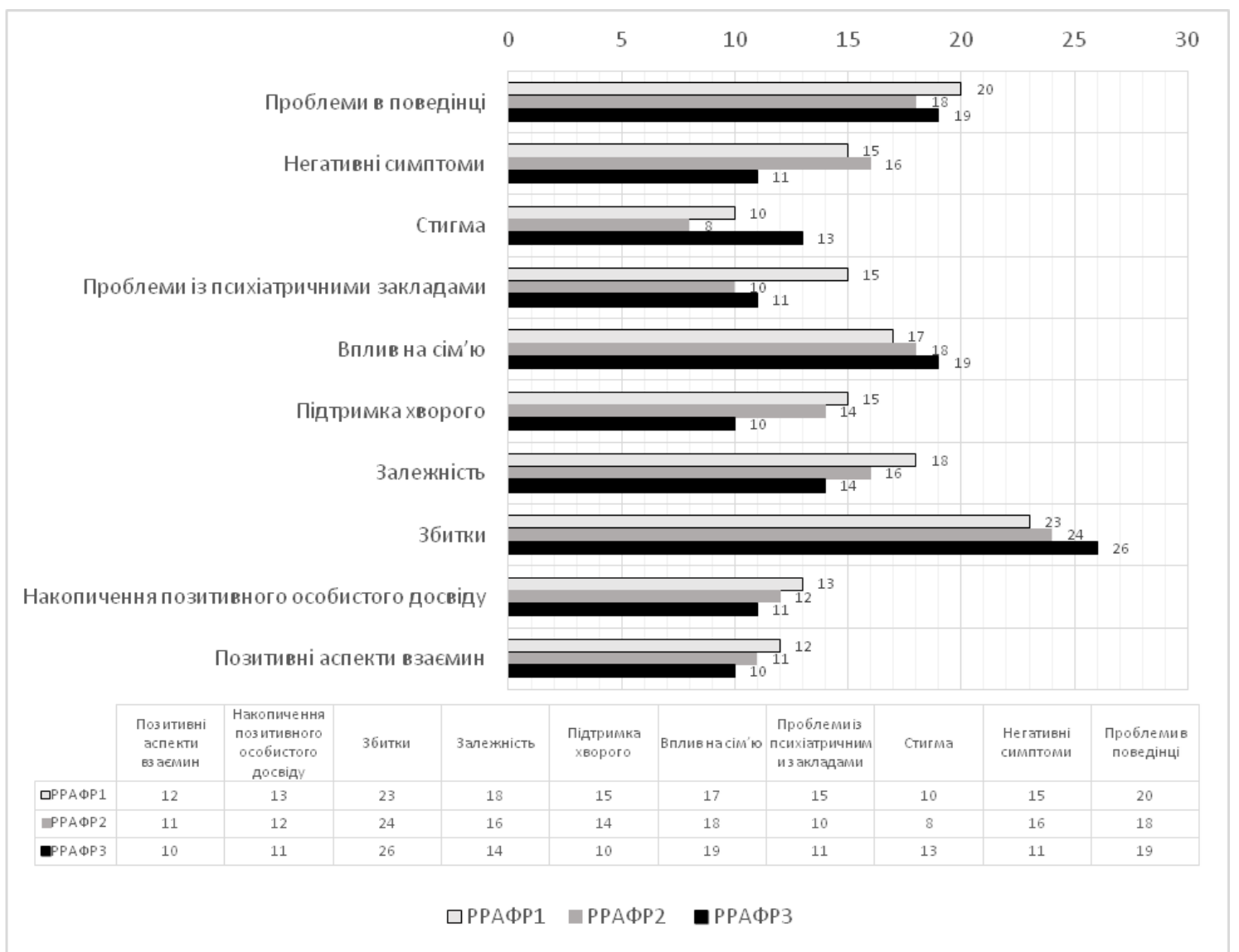

Рис. 2. Рівень сімейного навантаження на референтних родичів пацієнтів з афективними розладами залежно від тривалості захворювання

ливого, підозрілого, дивного на вигляд та у поведінці за конструктом «проблеми в поведінці». У респондентів РРПШ високі показники за параметром «негативні симптоми» вказують на схильність РР оцінювати психічно хворого члена сім'ї як схильного до усамітнення, нетовариського, незацікавленого, повільного, безвідповідального або нерішучого, що пояснюється настанням особистісних змін пацієнта та відображає нерозуміння референтними родичами зв'язку цих змін із наявністю психічного захворювання.

Показники за конструктом «стигма» демонструють прагнення РР приховувати захворювання члена сім'ї; нездатність розповісти кому-небудь про наявність в сім'ї психічного захворювання; пов'язане 3 цим уникання соціальних контактів; незнання як пояснювати симптоми іншим; почуття сорому через наявність психічно хворого родича.

Конструкт «проблеми з установами, що обслуговують психічно хворих» вказує, що на думку РР, співробітники, які обслуговують психічно хворих, не сприймають їх достатньо серйозно та не ставляться до проблеми їх родича із достатнім розумінням; а також невміння викласти скарги з приводу догляду за хворим; труднощі щодо отримання інформації про його хвороби.

Конструкт «вплив на сім'ю» відображає зіткнення РP із нерозумінням з боку інших членів сім'ї, розривом стосунків через небажання жити разом із хворим; негативним впливом психічного стану паціснта на розвиток дітей; сприймання референтними родичами пацієнта як причини руйнування сім'ї, псування задоволення від сімейних подій та сімейного життя загалом.

За конструктом «підтримка хворого» 3'ясовано, що як респонденти РРПШ, так і респонденти РРАФР оцінюють хворого члена сім'ї, як такого, що не знає, як поводитись 3 грошима; через що їм доводиться забезпечувати або субсидувати його, коли у нього закінчуються гроші; хвороба завдає удар по сімейному бюджету; доводиться забезпечувати пацієнту житло; стежити, щоб він не зв'язався з поганою компанією.

За конструктом «залежність» показники $€$ дещо вищими у респондентів РРАФР, хоча 
мають тенденцію до поступового зниження. Цей розділ відображає нездатність РР робити те, що вони бажають через постійні тривожні думки про психічно хворого родича, який сприймається як безпорадний та залежний; якому потрібно допомагати чимось заповнити свій день; якого РР остерігаються залишати самого в будинку.

Виразне зростання показників сімейного навантаження за розділом «збиток» в обох основних групах відображає роздуми РР про те, яке життя у них могло би бути; самозвинувачення та відчуття небезпеки, що пацієнт спробує скоїти самогубство; занепокоєння думками про смерть, втрачені можливості; побоювання, що пацієнт намагатиметься завдати собі шкоди; невіра у покращення його стану.

Конструкт «накопичення позитивного особистого досвіду», де динаміка є негативною як у респондентів РРПШ, так і в респондентів РРАФР, відображає поступову втрату у них здатності до отримання позитивного досвіду сімейної взаємодії з пацієнтом, зокрема використовувати таку взаємодію як спосіб більше дізнатись про себе, допомагати іншим зрозуміти, наскільки серйозно він хворий; отримання впевненості у собі шляхом спілкування 3 іншими людьми, розуміння проблем інших людей, зближення з друзями, нові знайомства, надбання гідності.

Так само виявлено поступове зниження показників у конструкті «позитивні аспекти взаємин», що вказує на схильність РР знецінювати свою роль у забезпеченні добробуту психічно хворого члена сім'ї, а також заперечення здатності пацієнта бути корисним, демонструвати силу волі, намагаючись впоратись зі своєю хворобою; здатність до приємного спілкування; спільність інтересів.

Результати подальшого дослідження респондентів за шкалою структурованого інтерв'ю для визначення ставлення членів сім'ї до психіатричного діагнозу у близького члена сім'ї дозволили виявити деякі відмінності між РРПШ та РРАФР (таблиия).

Так, 42,8 \% обстежених нами РР паціснтів 3 ПШ і 37,3 \% РР пацієнтів з АФР виявили драматизуючий тип ставлення до стану психічно хворого члена сім'ї, проявами чого були катастрофізація сімейної ситуації, переоцінка членами сім'ї важкості хвороби із переживаннями занепокоєння, розгубленістю, почуттям провини та недовіри до лікарів; очікуванням негативних наслідків хвороби для членів сім'ї; впевненістю, що хвороба привноситиме у внутрішній світ хворого хаос і безлад, виб'є його з колії, зі звичних життєвих відносин, позбавить перспективи та зробить безпорадним; а також низька готовність допомагати хворому у дотриманні терапевтичного режиму.

У 29,8 \% РР пацієнтів з ПШ і у 44,6 \% РP пацієнтів 3 АФР переважав адекватний тип ставлення до захворювання. Адекватне ставлення виявлялось у достатньому розумінні реальної складності захворювання, концептуалізації хвороби, усвідомленій готовності виконувати рекомендації лікаря, реалістичних очікуваннях від лікувальних заходів. Такі сім'ї характеризуються прагненням прийняти факт хвороби та пов'язані 3 нею проблеми, здатністю брати на себе відповідальність за підтримку пацієнта у всіх сферах соціальної взаємодії.

Натомість у 27,4 \% респондентів ОГПШ та $18,1 \%$ респондентів ОГАФР було виявлено негативне (деструктивне) ставлення до психічного стану хворого члена сім'ї, що виявлялось у нерозумінні або ігноруванні хвороби, ставленні до неї як до життєвої події, яка порушує подальший розвиток сім'ї та якість іiі життя; самоусунення від активної участі у долі пацієнта, повна безконтрольність, невіра в можливість позитивної терапевтичної перспективи.

Подальше дослідження типу суб'єктивного ставлення референтних родичів до наявності

Типи ставлення референтних родичів до пащієнта

з ендогенним психічним захворюванням залежно від тривалості захворювання

\begin{tabular}{|c|c|c|c|c|c|c|}
\hline Типи & \multicolumn{3}{|c|}{ РРПШ (n=168) } & \multicolumn{3}{|c|}{ РРАФР $(n=75)$} \\
\hline \multirow[t]{4}{*}{ Негативний } & \multicolumn{3}{|c|}{$27,40 \%$} & \multicolumn{3}{|c|}{$18,10 \%$} \\
\hline & \multicolumn{6}{|c|}{ Тривалість захворювання } \\
\hline & $0-4 \mathrm{p}$ & $5-8 \mathrm{p}$. & 9-12 p. & $0-4 \mathrm{p}$. & $5-8 \mathrm{p}$ & 9-12 p. \\
\hline & $\begin{array}{c}\text { РРПШ1 } \\
(n=57)\end{array}$ & $\begin{array}{c}\text { РРПШ2 } \\
(n=58)\end{array}$ & $\begin{array}{c}\text { РРПШ3 } \\
(n=53)\end{array}$ & $\begin{array}{c}\text { PРАФР1 } \\
(n=34)\end{array}$ & $\begin{array}{c}\text { PРAФP2 } \\
(n=22)\end{array}$ & $\begin{array}{c}\text { РРАФРЗ } \\
(n=19)\end{array}$ \\
\hline Драматизуючий & $36,8 \%$ & $39,8 \%$ & $31,8 \%$ & $25,2 \%$ & $23,2 \%$ & $21,8 \%$ \\
\hline Негативний & $17,9 \%$ & $24,4 \%$ & $40,5 \%$ & $11,7 \%$ & $19,9 \%$ & $28,9 \%$ \\
\hline
\end{tabular}


психічного захворювання у члена сім'ї в клінікодинамічному аспекті виявило певні особливості, які необхідно враховувати при розробці відповідної системи медико-психологічного супроводу для сімей, де проживають хворі з ЕПР.

Як свідчать отримані дані (рис. 3), при загальній тривалості хвороби до 4-х років, адекватний тип ставлення до хвороби переважає у всіх групах, обстежених нами референтних родичів пацієнтів з ЕПР (РРПШ1 45,3 \%; РРАФР1 63,1\%), що є сприятливою переду- стеми сімейного гомеостазу за таких умов призводять до зниження здатності до адекватного сприйняття нової інформації щодо перебігу хвороби пацієнтів. Увага акцентувалась на тому, що хвороба призведе до значних змін у звичному житті, детермінує міжособистісні стосунки до рівня негативно забарвлених, позбавить життєвих перспектив. Будь-які призначення лікаря викликали занепокоєння з боку РР, посилювали недовіру до лікаря та діагнозу 3 одного боку, а з іншого - виявлялась обме-

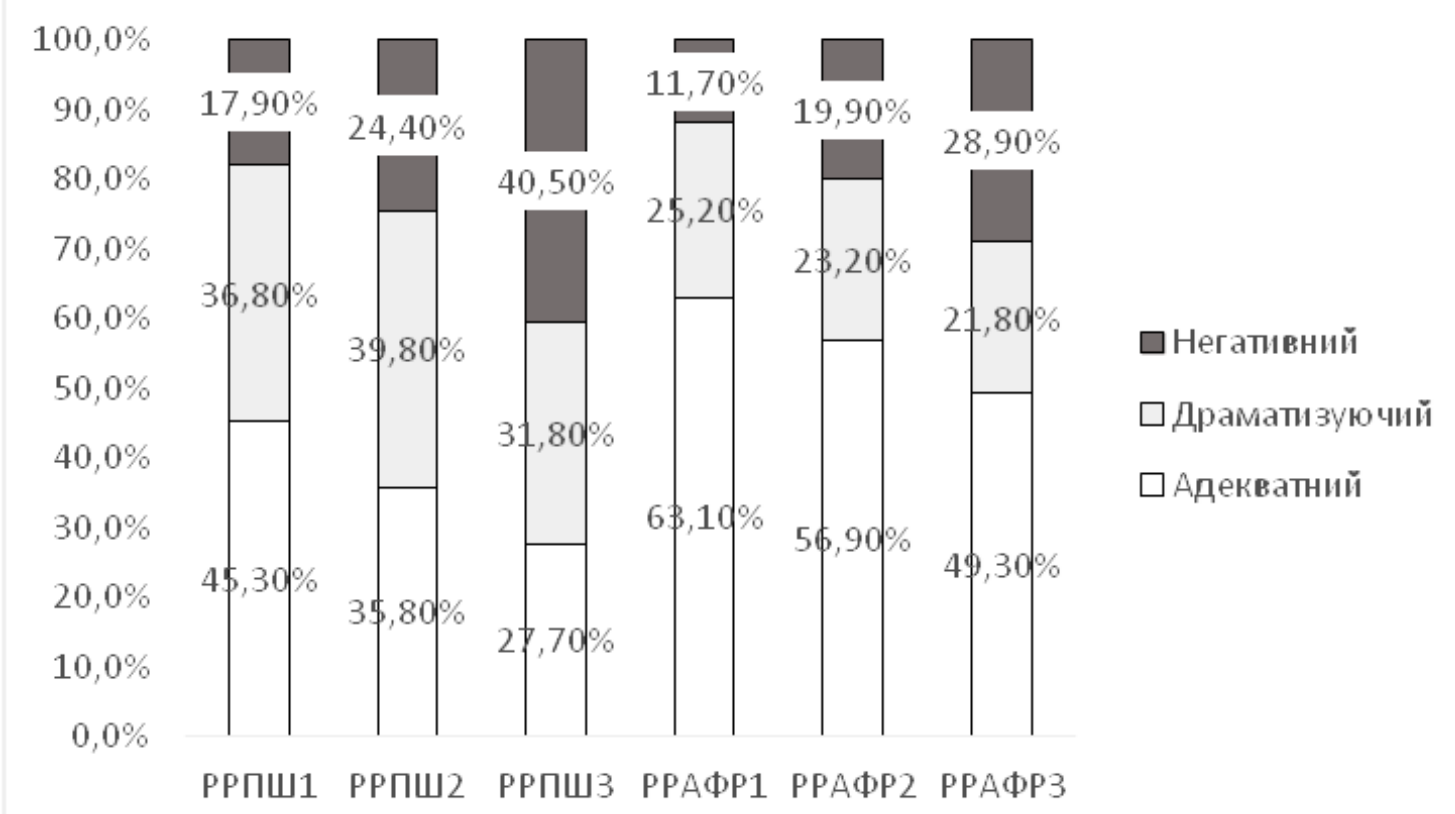

Рис. 3. Динаміка типу ставлення до захворювання залежно від тривалості захворювання

мовою для впровадження медико-психологічного супроводу, оскільки в цей період зберігається достатне розуміння можливих труднощів, концептуалізація страждання, усвідомлена готовність виконувати рекомендації лікаря, $\epsilon$ реальні очікування від лікувальних заходів. Сім'я повністю усвідомлює наявність проблем та труднощів, які можуть виникати при лікуванні хворого, проте зберігає надію та налаштовується на позитивний результат.

При тривалості захворювання у пацієнта від 5 до 8 років в обох групах РР спостерігається зниження кількості осіб з адекватним типом ставлення (адекватний тип - РРПШ2 35,8 \%; РРАФР2 56,9 \%) та зростання кількості респондентів 3 драматизуючим типом ставлення (драматизуючий тип - РРПШ2 39,8 \%; РРАФР2 $23,2 \%)$. Це вказує на виснаження адаптивних ресурсів сімейної системи, що супроводжується зростанням тривожності, переоцінкою важкості хвороби, розпачем, відчуттями провини та безнадії, недовірою до лікарських призначень. Тривожні очікування та порушення си- жена готовність допомагати хворому підтримувати відповідний терапевтичний режим.

При тривалості хвороби більш ніж 8 років, на фоні зменшення поширеності драматизуючого та адекватного типів відношення до хвороби у пацієнта, прослідковується помітне наростання поширення негативного суб'єктивного ставлення до хвороби у пацієнта 3 боку референтних родичів (негативний тип РРПШЗ 40,5 \%; РРАФР3 28,9 \%). Негативне (деструктивне) ставлення 3 боку референтних родичів проявлялось у бажанні дистанціюватись від проблеми, нерозумінні та ігноруванні хвороби близької людини. Респонденти РРПШ3 та РРАФР3 вбачали у факті наявної хвороби загрозу для власного благополуччя, нівелювали значущість пов'язаних зі здоров'ям пацієнтів ситуацій, відмежовувались від активної участі у лікуванні та відповідальності за долю пацієнта, а думки про безперспективність майбутнього посилювали недовіру щодо позитивного терапевтичного ефекту в подальшому лікуванні хворих. Негативно за- 
барвлене ставлення до психічно хворого члена сім'ї може пояснюватись нерозумінням через відсутність достатньої кількості інформації про хворобу, появою почуттів самотності та втрати, пов'язаних із прогресуючими особистісними змінами, обумовленими захворюванням, відмовою від надії на майбутнє, розчаруванням у сприятливому перебігу хвороби.

Дослідження типології відношення референтних родичів в сім'ях, де проживає хворий на ЕПР дозволило виділити певні особливості, які визначались загальною тривалістю патологічного процесу у пацієнтів. Так, на початкових етапах розвитку хвороби (до 4-х років) переважає адекватний тип ставлення референтних родичів до хвороби пацієнта, що створює сприятливе підгрунтя для медико-психологічних втручань. У міру розвитку патологічного процесу, домінуючу позицію займають драматизуючий та негативний типи відношення з боку референтних родичів $(\mathrm{P}<0,001)$.

Встановлені особливості свідчать про те, що в процесі розвитку ендогенного психічного розладу у члена сім'ї у референтних родичів поступово зростає рівень сімейного навантаження за всіма конструктами з одночасним виснаженням емоційних, індивідуально-психологічних та комунікативних ресурсів, що зрештою призводить до дистанціювання й уникання в ситуаціях внутрішньосімейної взаємодії.

\section{Висновки}

Прийняття хвороби сім'єю та усвідомлене ставлення до її проявів у поєднанні з готовністю брати участь у забезпеченні психосоціальної реабілітації та реадаптації психічно хворого члена сім'ї - важливий фактор у лікуванні ендогенних психічних розладів. В сім'ях хворих на ЕПР практично повсякчас існують проблеми усвідомлення та прийняття особистісних та поведінкових змін члена сім'ї, які є наслідком проявів хвороби. Як правило, у більшості референтних родичів зберігається формальне та поверхневе прийняття хвороби. Недооцінюючи значення ендогенних психічних розладів, референтні родичі висувають до пацієнтів завищені вимоги, яким хворі з ЕПР не здатні відповідати. Така ситуація призводить до зростання конфліктності та дисфункціональності сімейної системи в цілому, появи комунікативних бар'єрів, наслідком чого може бути як екзацербація психічного розладу у пацієнта з ЕПР, так і загальне зниження якості життя усіх членів сім'ї.

Перспективою для подальших досліджень $\epsilon$ врахування виявлених психосоціальних особливостей функціонування сім'ї, де проживає хворий, при розробці та впровадженні відповідної системи медико-психологічного супроводу для референтних родичів пацієнтів 3 ендогенними психічними розладами.

\section{Література}

1. Гусева О. В. Интегративная модель психотерапии эндогенных психических расстройств / О. В. Гусева, А. П. Коцюбинский. - Издательство «СПЕЦЛИТ», 2013. - 287 с.

2. Awad A. G. The burden of schizophrenia on caregivers: a review / A. G. Awad, L. N. Voruganti // Pharmacoeconomics. - 2008. - №26 (2). - P. 149-162.

3. Райгородский Д. Я. Практическая психодиагностика. Методики и тесты / Райгородский Д. Я. Самара: Издательский дом «БАХРАХ-М», 2008. - 672 с.

4. Савельева О. В. Эффективность комплексной реабилитации больных шизофренией / О. В. Савельева, Н. Н. Петрова // Вестник СПбГУ. Серия 11. Медицина. - 2017. - №3. Режим доступа:

https://cyberleninka.ru/article/n/effektivnost-kompleksnoy-reabilitatsii-bolnyh-shizofreniey (дата обращения: 09.01.2019).

5. Эйдемиллер Э. Г. Психология и психотерапия семьи / Э. Г. Эйдемиллер, В. Юстицкис. - СПб, 1999. - С. $38 ; 555-556$.

6. Бугорский А. В. Психиатрическое просвещение родственников пациентов, страдающих шизофренией и расстройствами шизофренического спектра / А. В. Бугорский // Психотерапия и психосоциальная работа в психиатрии. Выпуск IV; под ред. О. В. Лиманкина, С. М. Бабина. - СПб.: Издательство «Таро», 2017. - С. 49-56.

7. Гурович И. Я. Практикум по психосоциальному лечению и психосоциальной реабилитации психически больных / И. Я. Гурович, А. Б. Шмуклер, Л. И. Сальникова. - М.: Медиапрактика, 2002. $-180 \mathrm{c}$.

8. Evaluation of the acceptability and usefulness of an information website for caregivers of people with bipolar disorder / L. Berk, M. Berk, S. Dodd [et al.] // BMC Medicine. - 2013. - № 11 (1). - P. 162.

9. The psychosocial treatment of schizophrenia: an update / J. Bustillo, J. Lauriello, W. Horan [et al.] // The American journal of psychiatry. - 2001. - № 158 (2). - P. 163-175. 
10. Do needs, symptoms or disability of outpatients with schizophrenia influence family burden? / S. Ochoa, M. Vilaplana, J. M. Haro [et al.] // Soc Psychiatry Psychiatr Epidemiol. - 2008. - № 43 (8). P. 612-618.

11. Assessing Health Status in Informal Schizophrenia Caregivers Compared with Health Status in Non-Caregivers and Caregivers of Other Conditions / S. Gupta, G. Isherwood, K. Jones [et al.] // BMC Psychiatry. - 2015. - № 15. - Published 2015 Jul 21. Doi:10.1186/s12888-015-0547-1

12. Miklowitz D. J. Family Treatment for Bipolar Disorder and Substance Abuse in Late Adolescence / D. J. Miklowitz // Journal of Clinical Psychology. - 2012. - № 68 (5). - P. 502-513.

13. Caregiver Burden and Health in Bipolar Disorder: A Cluster Analytic Approach / D. A. Perlick, R. A. Rosenheck, D. J. Miklowitz [et al.] // The Journal of nervous and mental disease. - 2008. - № 196 (6). - P. 484-491.

14. Burden of Care on Caregivers of Schizophrenia Patients: A Correlation to Personality and Coping / D. Geriani, K. S. Savithry, S. Shivakumar [et al.] // Journal of clinical and diagnostic research. - 2015. № 9 (3). - VC01-VC04. Published online 2015, Mar 1. Doi: 10.7860/JCDR/2015/11342.5654

15. Vitaliano P. P. Is Caregiving Hazardous to One's Physical Health A Meta-Analysis / P. P. Vitaliano, J. Zhang, J. M. Scanlan // Psychological Bulletin. - 2003. - № 129 (6). - P. 946-972.

\section{References}

1. Guseva O.V., Kotsyubinskiy A.P. (2013). Integrativnaya model psikhoterapii endogennykh psikhicheskikh rasstroystv [An integrative model of psychotherapy for endogenic psychiatric disorders]. Izdatelstvo "SPETSLIT", 287 p. [in Russian].

2. Awad A.G., Voruganti L.N. (2008). The burden of schizophrenia on caregivers: a review. Pharmacoeconomics, № 26 (2), pp. 149-162.

3. Raygorodskiy D.Ya. (2008). Prakticheskaya psikhodiagnostika. Metodiki $i$ testy [Practical psychodiagnostics. Methods and tests]. Samara. Izdatelskiy dom "BAKHRAKH-M", 672 p. [in Russian].

4. Saveleva O.V., Petrova N.N. (2017). Effektyvnost kompleksnoi reabylytatsyi bolnikh shyzofrenyei [The effectiveness of complex rehabilitation of patients with schizophrenia]. Vestnyk SPbHU, Seryia 11, Medytsyna - Bulletin of St. Petersburg State University. Series 11, Medicine, № 3. URL: https://cyberleninka.ru/article/n/effektivnost-kompleksnoy-reabilitatsii-bolnyh-shizofreniey (data obrashchenyia: 09.01.2019) [in Russian].

5. Eydemiller E.G., Yustitskis V. (1999). Psikhologiya i psikhoterapiya semi [Family psychology and psychotherapy]. SPb. pp. 38, 555-556 [in Russian].

6. Bugorskiy A.V. (2017). Psikhiatricheskoye prosveshcheniye rodstvennikov patsiyentov, stradayushchikh shizofreniyey i rasstroystvami shizofrenicheskogo spektra [Psychiatric education of relatives of patients with schizophrenia and disorders of the schizophrenic spectrum]. Psikhoterapiya $i$ psikhosotsialnaya rabota $v$ psikhiatrii - Psychotherapy and psychosocial work in psychiatry. O. V. Limankina, S. M. Babina. [Ed.], Issue IV, SPb.: Izdatelstvo "Taro", pp. 49-56 [in Russian].

7. Gurovich I.Ya., Shmukler A.B., Salnikova L.I. (2002). Praktikum po psikhosotsialnomu lecheniyu i psikhosotsialnoy reabilitatsii psikhicheski bolnykh [Guide for psychosocial treatment and psychosocial rehabilitation of the mentally ill patients]. Moscow: Mediapraktika, 180 p. [in Russian].

8. Berk L., Berk M., Dodd S. et al. (2013). Evaluation of the acceptability and usefulness of an information website for caregivers of people with bipolar disorder. BMC Medicine, № 11 (1), pp. 162.

9. Bustillo J., Lauriello J., Horan W. et al. (2001). The psychosocial treatment of schizophrenia: An update. The American journal of psychiatry, № 158 (2), pp. 163-175.

10. Ochoa S., Vilaplana M., Haro J.M et al. (2008). Do needs, symptoms or disability of outpatients with schizophrenia influence family burden? Soc Psychiatry Psychiatr Epidemiol, № 43 (8), pp. 612-618.

11. Gupta S., Isherwood G., Jones K. et al. (2015). Assessing Health Status in Informal Schizophrenia Caregivers Compared with Health Status in Non - Caregivers and Caregivers of Other Conditions. BMC Psychiatry, № 15. Published 2015 Jul 21. doi:10.1186/s12888-015-0547-1

12. Miklowitz D.J. (2012). Family Treatment for Bipolar Disorder and Substance Abuse in Late Adolescence. Journal of Clinical Psychology, № 68 (5), pp. 502-513.

13. Perlick D.A., Rosenheck R.A., Miklowitz D.J. et al (2008). Caregiver Burden and Health in Bipolar Disorder: A Cluster Analytic Approach. The Journal of nervous and mental disease, № 196 (6), pp. 484-491.

14. Geriani D., Savithry K.S., Shivakumar S. et al. (2015). Burden of Care on Caregivers of Schizophrenia Patients: A Correlation to Personality and Coping. Journal of clinical and diagnostic research, № 9 (3). VC01-VC04. Published online 2015 Mar 1. doi: 10.7860/JCDR/2015/11342.5654

15. Vitaliano P.P., Zhang J., Scanlan J.M. (2003). Is Caregiving Hazardous to One's Physical Health A Meta-Analysis. Psychological Bulletin, № 129 (6), pp. 946-972. 


\section{А.А. Каминская, Н.К. Агишева}

\section{ПСИХОСОЦИАЛЬНЫЙ КОНТЕКСТ ФУНКЦИОНИРОВАНИЯ СЕМЬИ, ГДЕ ПРОЖИВАЕТ БОЛЬНОЙ С ЭНДОГЕННЫМ ПСИХИЧЕСКИМ РАССТРОЙСТВОМ}

Исследовали психосоциальные особенности референтных родственников пациентов с эндогенными психическими расстройствами. Было обследовано 243 референтных родственника больных параноидной шизофренией (168 человек) и больных с аффективными расстройствами (75 человек). Группу контроля составили 55 психически здоровых лиц. В исследовании были использованы шкала оценки нагрузки на семью (ECI, Experience of Caregiving Inventory) по G. Szmukler et al. (1994) и шкала структурированного интервью для определения отношения членов семьи к наличию болезни (психиатрического диагноза) у родственника по В.А. Абрамову, И.В. Жигулиной, Т.Л. Ряполовой. Установленные особенности свидетельствуют о том, что в процессе развития эндогенного психического расстройства у члена семьи у референтных родственников постепенно нарастает уровень семейной нагрузки по всем конструктам с одновременным истощением эмоциональных, индивидуально-психологических и коммуникативных ресурсов. Исследование типологии отношения референтных родственников к наличию психического заболевания у члена семьи позволило выделить некоторые особенности, которые определялись общей продолжительностью патологического процесса у пациентов. Так, на начальных этапах развития болезни (до 4-х лет) преобладал адекватный тип отношения, что создает благоприятную почву для медико-психологических вмешательств. В процессе развития патологического процесса со стороны референтных родственников начинали преобладать драматизирующий и негативный типы отношения $(\mathrm{P}<0,001)$. Принятие болезни семьей и осознанное отношение к ее проявлениям в сочетании с психологической готовностью участвовать в обеспечении психосоциальной реабилитации и реадаптации психически больного члена семьи важный фактор в лечении эндогенных психических расстройств.

Ключевые слова: ресоциилизачия, референтные родственники, дистресс, психически больные, внутрисемейные факторы.

\section{A.O. Kaminska, N.K. Agisheva \\ PSYCHOSOCIAL CONTEXT OF FUNCTIONING IN FAMILIES WHERE A PATIENT WITH ENDOGENOUS MENTAL DISORDER LIVES}

Studying psychosocial features of family caregivers is of particular importance, which is explained by the need for appropriate system of medical-psychological support directly for family members of patients in order to provide optimal disclosure of family social-therapeutic potential. In total 243 family caregivers of patients with paranoid schizophrenia (168 people) and affective disorders ( 75 people) were included into the study. Control group comprised 55 mentally healthy persons. Experience of Caregiving Inventory (ECI) by G. Szmukler et al. (1994) and Structured Interview Scale of Family Members Attitude to the Disease (psychiatric diagnosis) in a Family Member by V.A. Abramov, I.V. Zhigulina, T.L. Riapolova were used as psychological testing tools. Revealed features indicate that within the process of development of an endogenous mental disorder in a family member, level of family burden gradually increases while emotional, individual psychological and communicative resources of family members get simultaneously exhausted. Study of typology of family caregivers' attitude to a mental illness diagnosis in a family member, made it possible to distinguish certain features that were determined by the overall duration of pathological process in patients. Thus, during the early stages of disease (up to 4 years), an adequate type of attitude prevailed, which creates a favorable basis for medical-psychological interventions. Within the pathological process development, family caregivers developed dramatizing and negative types of attitude $(\mathrm{P}<0.001)$. Accepting of the disease by family and conscious attitude towards its manifestations, combined with psychological readiness to participate in providing psychosocial rehabilitation and readapting of mentally sick family member are important factors in treatment of endogenous mental disorders.

Keywords: re-socialization, referral relatives, distress, mentally ill, intra-family factors. 


\section{Контактна інформація}

Камінська Анна Олексї̈ва - кандидат медичних наук, доцент, доцент кафедри медичної психології і психіатрії з курсом післядипломної освіти Вінницького національного медичного університету ім. М.І. Пирогова.

Адреса: Україна, 21018, м. Вінниця, вул. Пирогова, 56, Вінницький національний медичний університет ім. М.I. Пирогова.

Тел.: +380979719887.

E-mail:. kamynskaanna@gmail.com.

ORCID: 0000-0002-6288-5890.

Агішева Наїля Каїсівна - кандидат психологічних наук, доцент, доцент кафедри сексології, медичної психології, медичної і психологічної реабілітації Харківської медичної академії післядипломної освіти.

Адреса: Україна, 61176, м. Харків, вул. Амосова, 58.

Тел.: +380974919189.

E-mail: agisevanaila085@gmail.com.

ORCID: 0000-0003-0332-8952. 